\title{
ANALISIS PERTANGGUNGJAWABAN HUKUM PIDANA DOKTER SPESIALIS KANDUNGAN DAN KEBIDANAN PADA KASUS PASIEN DENGAN KELAINAN KONGENITAL
}

\author{
Sigit Setiaji \\ Email:ad71ku@yahoo.com \\ Mahasiswa Program Magister Ilmu Hukum Program Pascasarjana \\ Fakultas Hukum Universitas Sebelas Maret Surakarta \\ Isharyanto \\ Email: masis_uns@yahoo.com \\ Adi Sulistiyono \\ Email: adi_sumo@yahoo.com.id \\ Dosen Fakultas Hukum Universitas Sebelas Maret Surakarta
}

\begin{abstract}
This paper analyzes the criminal liability of obstetricians and gynecologists in case of patients with congenital abnormalities. Congenital abnormalities in the patient cause the baby to be born disabled. Such circumstances cause the patient to suspect that there has been a medical malpractice in the medical treatment provided by obstetricians and gynecologists. This paper is a normative legal research that is prescriptive with the approach of law and conceptual approach. Techniques of collecting legal materials using literature studies and techniques of analysis of legal materials using methods of deduction. This paper concludes that the case of patients with congenital abnormalities is not a medical malpractice, but rather a medical risks. There is no causality between the medical treatment given by the obstetrician and gynecologists with the congenital abnormalities suffered by the patient. Criminal liability can not be applied to this case. This paper recommends the addition of provisions medical malpractice and medical risks in Law No. 29 of 2004 on Medical Practice to provide legal certainty to the medical profession and patients in the practice of health services.
\end{abstract}

Keywords: congenital abnormalities, criminal liability, obstetrician and gynecologists, patient.

\begin{abstract}
Abstrak
Tulisan ini menganalisis pertanggungjawaban hukum pidana dokter spesialis kandungan dan kebidanan pada kasus pasien dengan kelainan kongenital. Kelainan kongenital pada pasien menyebabkan bayi terlahir cacat. Keadaan demikian menyebabkan pasien menduga bahwa telah terjadi malpraktek medis pada tindakan medis yang diberikan oleh dokter spesialis kandungan dan kebidanan. Tulisan ini
\end{abstract}


merupakan penelitian hukum normatif yang bersifat preskiptif dengan pendekatan undang-undang dan pendekatan konseptual. Teknik pengumpulan bahan hukum menggunakan studi pustaka dan teknik analisis bahan hukum menggunakan metode deduksi. Tulisan ini menyimpulkan bahwa kasus pasien dengan kelainan kongenital bukan merupakan malpraktek medis, melainkan resiko medis. Tidak terdapat kausalitas antara tindakan medis yang diberikan oleh dokter spesialis kandungan dan kebidanan dengan kelainan kongenital yang diderita pasien. Pertanggungjawaban hukum pidana tidak dapat diterapkan pada kasus ini. Tulisan ini merekomendasikan ditambahkannya ketentuan yang mengatur tentang malpraktek medis dan resiko medis di dalam Undang-Undang Nomor 29 Tahun 2004 tentang Praktek Kedokteran untuk memberikan kepastian hukum pada profesi kedokteran maupun pasien dalam praktek penyelenggaraan pelayanan kesehatan.

Kata kunci: dokter spesialis kandungan dan kebidanan, kelainan kongenital, pertanggungjawaban hukum pidana, pasien.

\section{A. Pendahuluan}

Profesi dokter dituntut memiliki etika, moral, dan keahlian dalam melaksanakan praktek kedokteran yang merupakan rangkaian kegiatan pelayanan kesehatan sebagaimana dilakukan oleh dokter dan dokter gigi terhadap pasien yang tercantum dalam Undang-Undang Nomor 29 Tahun 2004 tentang Praktek Kedokteran. Dokter selalu dituntut untuk berusaha sebaik mungkin dalam merawat pasiennya dan setiap tindakan yang ia lakukan harus sesuai dengan standar profesi kedokteran (Rosa Elita dan Yusuf Shofie, 2007: 12). Dalam pelayanan kesehatan, cara bekerja dokter dalam menangani seorang pasien adalah antara kemungkinan dan ketidakpastian karena tubuh manusia bersifat kompleks (J. Guwandi, 2009: 3).

Terjadi permasalahan ketika dokter spesialis kandungan dan kebidanan mendapati pasien yang mempunyai kelainan kongenital. Dalam terapi yang diberikan oleh dokter spesialis kandungan dan kebidanan, kelainan kongenital yang diderita pasien kerap kali tidak dapat dideteksi sejak dini karena didapatinya kelainan kongenital tergantung pada posisi janin yang terkadang tidak mendukung analisa dan teknologi yang sudah ada saat ini. Ketika bayi lahir dengan kondisi cacat bawaan, orang tua cenderung tidak bisa menerima kenyataan dan lebih memilih untuk menyalahkan keadaan bayinya pada dokter spesialis kandungan dan kebidanan yang 
menangani dengan tuduhan dokter spesialis kandungan dan kebidanan sudah melakukan malpraktek medis, padahal dokter spesialis kandungan dan kebidanan sudah melakukan tindakan medis yang diperlukan demi dapat dilahirkannya bayi dengan normal dan selamat.

Malpraktek medis sering dikaburkan dengan apa yang dimaksud dengan resiko medis. Sehingga tidak jarang seorang dokter yang telah bekerja dengan profesional yaitu telah sesuai dengan standar profesi medik, standar pelayanan medis, serta Standar Operasional Prosedur (SOP) masih dituntut dengan tuduhan telah melakukan malpraktek medis. Mudah dimengerti karena dokter yang melakukan praktek kedokteran adalah manusia dengan segala kelebihan dan kekurangannya, tetapi yang terpenting lagi adalah karena praktek kedokteran merupakan serangkaian kegiatan yang kompleks. Praktek kedokteran betapapun berhati-hatinya dilaksanakan selalu berhadangan dengan kemungkinan terjadinya resiko medis

Dari peristiwa pelayanan kesehatan tersebutlah maka timbul suatu akibat hukum dalam pelayanan kesehatan dan diperlukan adanya pembahasan mendalam terkait pertanggungjawaban hukum pidana dokter spesialis kandungan dan kebidanan pada dugaan malpraktek medis kasus pasien dengan kelainan kongenital demi sebuah rasa aman yang dapat dirasakan oleh dokter spesialis kandungan dan kebidanan dalam melakukan pelayanan kesehatan.

\section{B. Metode Penelitian}

Metode penelitian yang digunakan dalam tulisan ini adalah metode penelitian hukum normatif dengan menggunakan metode studi kepustakaan. Bahan hukum yang digunakan adalah bahan hukum primer yang meliputi peraturan perundang-undangan mulai dari Undang-Undang Dasar Negara Republik Indonesia Tahun 1945, UndangUndang, dan peraturan perundang-undangan lainnya yang terkait dengan masalah penelitian. Sumber bahan hukum mencakup juga bahan hukum sekunder seperti buku-buku referensi, majalah hukum, jurnal hukum, surat kabar, dan hasil karya 
ilmiah yang relevan dengan topik penelitian (Peter Mahmud Marzuki, 2014: 237240).

\section{Hasil Penelitian Dan Pembahasan}

1. Pertanggungjawaban Hukum Pidana

a. Definisi Pertanggungjawaban Hukum

Menurut kamus hukum, pertanggungjawaban hukum adalah suatu akibat atas konsekuensi kebebasan seorang tentang perbuatannya yang berkaitan dengan etika atau moral dalam melakukan suatu perbuatan (Soekidjo Notoatmojo, 2010: 46). Pertanggungjawaban hukum harus mempunyai dasar, yaitu hal yang menyebabkan timbulnya hak hukum bagi seorang untuk menuntut orang lain sekaligus berupa hal yang melahirkan kewajiban hukum orang lain untuk memberi pertanggungjawabannya (Titik Triwulan dan Shinta Febrian, 2010: 48).

Keterikatan dokter terhadap ketentuan-ketentuan hukum dalam menjalankan profesinya merupakan tanggungjawab hukum yang harus dipenuhi oleh dokter yang salah satunya merupakan pertanggungjawaban hukum pidana. Kitab Undang-Undang Hukum Pidana tidak merumuskan pengertian pertanggungjawaban hukum pidana, akan tetapi secara konseptual Moeljatno mendefinisikan perbuatan pidana sebagai perbuatan yang dilarang oleh suatu aturan hukum, larangan mana disertai ancaman (sanksi) yang berupa pidana tertentu bagi barang siapa melanggar larangan tersebut. larangan ditujukan kepada perbuatan (suatu keadaan atau kejadian yang ditimbulkan oleh kelakuan orang), sedangkan ancaman pidana ditujukan kepada orang yang menimbulkan kejadian itu (Moeljatno, 1984: 54).

b. Konseptualisasi Pertanggungjawaban Hukum Pidana

Keterikatan dokter terhadap ketentuan-ketentuan hukum dalam menjalankan profesinya merupakan tanggungjawab hukum yang harus 
dipenuhi oleh dokter yang salah satunya adalah pertanggungjawaban hukum pidana apabila dalam menjalankan profesinya melakukan perbuatan pidana (Moeljatno, 1984: 54). Simons mengartikan perbuatan pidana sebagai suatu tindakan melanggar hukum yang telah dilakukan dengan sengaja ataupun tidak sengaja oleh seseorang yang dapat dipertanggungjawabkan atas tindakannya dan oleh undang-undang telah dinyatakan sebagai suatu perbuatan atau tindakan yang dapat dihukum (Leden Marpaung, 1991: 4).

Dipidananya seseorang tidaklah cukup apabila orang itu telah melakukan perbuatan yang bertentangan dengan hukum atau bersifat melawan hukum. Jadi meskipun perbuatannya memenuhi rumusan delik dalam undang-undang dan tidak dibenarkan, hal tersebut belum memenuhi syarat untuk penjatuhan pidana. Untuk pemidanaan masih perlu adanya syarat, yaitu bahwa orang yang melakukan perbuatan itu mempunyai kesalahan atau bersalah (subjective guilt) (Johnny Krisnan, 2008: 31-33).

Tanggung jawab pidana timbul jika pertama-tama dapat dibuktikan telah adanya kesalahan profesional, misalnya kesalahan dalam diagnosa atau kesalahan dalam cara pengobatan atau pun perawatan. Dari segi hukum, kelalaian adalah merupakan suatu perbuatan melawan hukum yang dilakukan oleh seseorang yang mampu bertanggungjawab. Kesalahan dalam tindak pidana medis umumnya adalah kesalahan yang dilakukan karena kelalaiannya seorang dokter. Dalam hukum pidana, penentuan atas kesalahan seseorang didasarkan atas hal-hal sebagai berikut: (i) Keadaan batin orang yang melakukan, dalam hal ini diisyaratkan bahwa disadari atau tidak disadari perbuatan pelaku dilarang oleh undang-undang; dan (ii) Adanya hubungan sikap batin antara pelaku dengan perbuatan yang dilakukan (Riza Alfiano Kurniawan, 2013: 152-153).

Untuk adanya pertanggungjawaban pidana diperlukan syarat bahwa pembuat mampu bertanggung jawab. Tidaklah mungkin seseorang dapat dipertanggungjawabkan apabila ia tidak mampu bertanggung jawab. ada 
beberapa faktor yang dapat menentukan apakah seseorang dapat mempertanggungjawabkan perbuatannya atau tidak, yang pertama adalah faktor akal, yaitu dapat membedakan antara perbuatan yang diperbolehkan dan yang tidak. Yang kedua adalah faktor perasaan atau kehendak, yaitu dapat menyesuaikan tingkah lakunya dengan keinsafan atas mana yang diperbolehkan dan yang tidak. Sebagai konsekuensinya, tentunya orang yang tidak mampu menentukan kehendaknya menurut keinsafan tentang baik dan buruknya perbuatan tadi, dia tidak mempunyai kesalahan. Orang yang demikian itu tidak dapat dipertanggungjawabkan. Selain beberapa faktor tersebut, ada juga faktor kesengajaan (de will) yang mempengaruhi pertanggungjawaban hukum seseorang. Beberapa sarjana merumuskan de will sebagai keinginan, kemauan, kehendak, dan perbuatan merupakan pelaksanaan dari kehendak. De Will dapat ditujukan terhadap perbuatan yang dilarang dan akibat yang dilarang. (Riza Alfiano Kurniawan, 2013: 38-39).

2. Kasus Kelainan Kongenital Sebagai Resiko Medis Dan Bukan Merupakan Malpraktek Medis

a. Konseptualisasi Kelainan Kongenital Sebagai Resiko Medis

Malpraktek medis dalam perspektif hukum pidana (criminal malpractice) mulai menjadi sorotan masyarakat seiring berkembangnya pengetahuan masyarakat akan hak yang dimilikinya dalam memperoleh pelayanan kesehatan. Criminal Malpractice terjadi jika dokter melanggar ketentuan hukum pidana. Pada criminal malpractice pembuktiannya didasarkan atas dipenuhi tidaknya unsur pidana (Wahyu Wiriadinata, 2014: 48). Masalah dapat mucul dalam tindakan medis dokter apabila ada kelalaian oleh dokter dalam melaksanakan tindakan medis tersebut. Untuk menentukan kelalaian dalam tindakan medis, dapat dilakukan melalui beberapa cara diantaranya (Wahyu Wiriadinata, 2014: 276):

1) Dereclition of Duty, yaitu tidak melaksanakan kewajiban yang seharusnya dilaksanakan 
2) Damage, yaitu timbulnya kerugian atau kecideraan

3) Direc Causation, yaitu adanya hubungan langsung antara kecideraan atau kerugian itu dengan kegagalan malaksanakan kewajiban.

Perbuatan-perbuatan tersebut diatas harus memenuhi perumusan delik pidana yaitu: Pertama, perbuatan tersebut baik positif maupun negatif merupakan perbuatan tercela (Actus Reus). Kedua, dilakukan dengan sikap batin yang salah yaitu berupa kesengajaan (Intensional), kecerobohan (Recklessness) atau kealpaan (Negligence), sehingga tanggungjawab selalu bersifat individual dan personal, tidak dapat dialihkan kepada orang lain atau rumah sakit. Beberapa contoh yang dapat dikategorikan sebagai criminal malpractice diantaranya adalah (Wahyu Wiriadinata, 2014: 276):

1) Kesengajaan, seperti melakukan aborsi tanpa indikasi medik, membocorkan rahasia kedokteran, tidak melakukan pertolongan kepada seseorang yang dalam keadaan darurat meskipun dia tahu tidak ada dokter lain yang menolongnya, menerbitkan surat keterangan dokter yang benar, membuat visum et revertum yang tidak benar, memberikan keterangan yang tidak benar disidang pengadilan dalam kapasitasnya sebagai ahli;

2) Kecerobohan, seperti melakukan tindakan medik yang tidak lege artis, melakukan tindakan medik tanpa informed consent; dan

3) Kealpaan, seperti kurang hati-hati sehingga meningalkan gunting dalam perut pasien, kurang hati-hati menyebabkan pasien luka-luka, kurang hatihati sehingga menyebabkan pasien meninggal dunia.

Dari pengertian criminal malpractice yang penulis paparkan diatas, tidak satupun yang sesuai dengan kriteria kasus pasien dengan kelainan kongenital. Hal ini dikarenakan kasus kelainan kongenital merupakan kelainan bawaan yang diderita pasien sehingga kelainan itu tidak disebabkan oleh tindakan medis yang dilakukan oleh dokter spesialis kandungan dan kebidanan. 
Adanya pendapat bahwa suatu tindakan medis yang dilakukan oleh dokter terhadap pasien haruslah berhasil, jika tidak maka itu merupakan malpraktek medis adalah sebuah kesesatan berfikir (fallacie). Pendapat demikian ini tidaklah benar, karena di dalam dunia medis selain malpraktek medis dikenal juga adanya resiko medis. Baik malpraktek medis maupun resiko medis dapat berakibat timbulnya kerugian yang diderita oleh pasien berupa luka, cacat bahkan kematian. Resiko medis merupakan suatu yang tidak dapat dipersalahkan, karena dokter telah berusaha semaksimal mungkin sesuai dengan standar profesi yang berlaku. Dalam hukum kesehatan, penilaian atas kegagalan dilakukannya tindakan medis bukanlah dilihat dari hasilnya, seperti tindakan medis yang mengakibatkan cacat, luka atau kematian pasien. Akan tetapi dari bagaimana upaya tindakan medis itu dilakukan, dengan kata lain tolok ukurnya adalah standar profesi (M.S. Ariijaal, hukumpedia.com, 2015: diakses pada pukul 11.05 WIB, tanggal 13 Agustus 2017).

Risiko medis merupakan suatu bentuk risiko yang bukan menjadi tanggung jawab dokter. Oleh karena itu, unsure-unsur resiko medis akan coba penulis uraikan menjadi beberapa kategori risiko yang tidak dapat dimintakan pertanggungjawaban atau risiko yang bukan menjadi tanggung jawab dokter, yaitu (Riza Alfiano Kurniawan, 2013:154-157):

1) Telah melakukan tindakan medis sesuai dengan standar profesi, standar medis dan standar operasional prosedur. Sebagaimana juga pernyataan di dalam Pasal 50 huruf a Undang-Undang Praktek Kedoteran, apabila seorang dokter telah melaksanakan pelayanan medis atau praktek kedokteran sesuai dengan standar profesi dan standar operasional maka ia (dokter dan dokter gigi) tersebut tidak dapat dituntut hukum baik secara perdata, pidana dan administrasi.

2) Keberadaan informed consent atau persetujuan tindakan medis. Sebelum melakukan tindakan medis, dokter berkewajiban memberikan penjelasan 
terhadap pasien dan atau keluarganya yaitu tentang diagnosis dan juga tata cara tindakan medis, tujuan untuk tindakan medis yang dilakukan, serta alternatif tindakan lain berikut risikonya yang akan terjadi. Adapun pengaturan mengenai persetujuan tindakan medis diatur dalam Pasal 39 dan 45 Undang-Undang Praktek Kedokteran. Selain itu persetujuan tindakan medis juga diatur secara khusus dalam Peraturan Menteri Kesehatan Nomor 290 Tahun 2008 tentang Persetujuan Tindakan Kedokteran. Dijelaskan bahwa, setiap tindakan kedokteran mesti mendapatkan persetujuan dari pasien setelah mendapatkan penjelasan yang lengkap mengenai bentuk-bentuk tindakan, alternatif tindakan dan risiko medis yang mungkin akan terjadi. Penjelasan atau informasi dapat diberikan secara tertulis ataupun secara lisan, yang mana penjelasan tersebut sekurang-kurangnya mencakup: (i) Diagnosis dan tata cara tindakan kedokteran; (ii) Tujuan tindakan kedokteran yang dilakukan; (iii) Alternatif tindakan lain dan risikonya; (iv) Risiko dan komplikasi yang mungkin terjadi; (v) Prognosis terhadap tindakan yang dilakukan; (vi) serta Perkiraan biaya. Setelah pasien memberikan persetujuan terhadap tindakan dokter berdasarkan syarat sebagaimana di atas, dan tindakan medis telah dilakukan sesuai dengan prosedur medis, dan sesuai dengan standar profesi dan standar operasional, maka bila terjadi satu kegagalan medis dokter tidak dapat dipersalahkan.

3) Contribution Negligence. Dokter tidak dapat dipersalahkan apabila dokter gagal atau tidak berhasil dalam penanganan pasiennya dikarenakan pasien tidak mau bekerjasama, atau pasien tidak kooperatif, tidak berkenan menjelaskan dengan jujur tentang suatu riwayat penyakit yang pernah dideritanya serta obat-obatan yang dikonsumsi sebelum pasien berobat kepada dokter yang bersangkutan. Atau bahkan pasien tidak melaksanakan apa yang telah dinasehatkan dokter kepada pasien. Hal ini pada dasarnya telah diatur dalam Pasal 50 Undang-Undang Praktek 
Kedokteran mengenai hak dokter, yang mana pada huruf c dinyatakan, dokter dan atau dokter gigi dalam melaksanakan praktiknya berhak mendapat informasi atau penjelasan yang lengkap dan jujur dari pasien atau keluarganya mengenai latar belakang kesehatan pasien. Dan sebaliknya, Pasal 51 Undang-Undang Praktek Kedokteran mengenai kewajiban dokter, yang mana dokter wajib memberikan pelayanan dan/atau rawatan kepada pasien dengan berdasarkan kepada standar medis dan standar operasional. Sedangkan dalam Pasal 52 huruf a Undang-Undang Praktek Kedokteran mengenai hak pasien menegaskan bahwa pasien berhak untuk mendapatkan penjelasan secara lengkap mengenai tindakan medis dari dokter. Artinya, kewajiban dokter berbanding lurus dengan hak pasien. Dan sebaliknya hak dokter juga berbanding lurus dengan kewajiban pasien. Pada suatu kegagalan medis yang disebabkan karena pasien tidak melaksanakan kewajibannya sebagaimana dalam Pasal 52 Undang-Undang Praktek Kedokteran adalah tidak dapat dipersalahkan kepada dokter.

4) Error of Judgment (kesalahan penilaian). Bidang kedokteran merupakan satu bidang yang amat komplek, seperti dalam suatu pengobatan sering terjadi ketidaksepakatan atau pendapat yang berlainan mengenai satu terapi penyembuhan penyakit. Menurut Munir Fuadi, ilmu medis adalah suatu gabungan dari suatu seni dan arts, di samping gabungan teknologi dan kematangan atau pengalaman dokter tersebut. Atas hal-hal yang demikian, di dalam prakteknya dapat muncul satu perbedaan pendekatan atau perbedaan penanganan terhadap suatu penyakit yang telah diderita pasien. Antara dokter yang satu dengan dokter yang lain cenderung terdapat perbedaan penanganan, namun hal demikian adalah dapat diperbolehkan sepanjang masih sesuai dengan standar medis maupun standar profesional dan operasional. Berdasarkan keadaan di atas muncul satu teori yang disebut dengan (respectable minority rule), yaitu 
seseorang dokter tidak dianggap berbuat lalai apabila ia memilih salah satu dari sekian banyak cara pengobatan yang diakui.

5) Volenti non fit injuria. Volenti non fit injuria adalah satu doktrin hukum yang dikenali juga sebagai Asumption of risk atau suatu anggapan bahwa pasien telah mengetahui adanya risiko yang akan terjadi. Apabila seseorang pasien telah mengetahui ada satu risiko dalam tindakan medis atas dirinya, tetapi ia tetap menyetujui tindakan tersebut, dan apabila nanti akan terjadi risiko sebagaimana telah dia ketahui sebelumnya, maka terhadap risiko itu tidak dapat dipersalahkan kepada dokter. Oleh karena itu, informasi atas penyakit dan risiko mesti diinformasikan kepada pasien sebelum dokter melakukan tindakan medis kepada pasien.

Resiko medis adalah suatu keadaan yang tidak dikehendaki baik oleh pasien maupun oleh dokter atau dokter gigi sendiri, setelah dokter atau dokter gigi berusaha semaksimal mungkin dengan telah memenuhi standar profesi, standar pelayanan medis dan standar operasional prosedur namun kecelakaan tetap terjadi juga. Resiko atau kecelakaan medis ini mengandung unsur yang tidak dapat dipersalahkan (verwijtbaarheid), tidak dapat di cegah (vermijtbaarheid) dan terjadinya tidak dapat diduga (verzinbaarheid) (Syahrul Machmud, 2008: 272-278).

Resiko medis juga dapat terjadi di semua tempat dilakukannya pengobatan, seperti di rumah sakit, klinik, praktik dokter, apotik, di rumah pasien, di tempat umum (pada kegiatan immunisasi), dan lain-lain. Bentuk resiko medis bermacam-macam, seperti: (i) kesalahan medis (medical error), (ii) kecelakaan medis (medical accident), (iii) kelalaian medis (medical negligence); dan lain sebagainya. Daldiyono menggunakan istilah "Resiko dari aspek upaya pengobatan" untuk merujuk pada definisi resiko medis yang artinya: "hasil yang tidak memuaskan, tidak diharapkan, yang sebagian tidak dapat diprediksi dalam proses pertolongan kepada orang sakit" (J.Guwandi, 2014: 104). 
Suatu hasil yang tidak diharapkan terjadi di dalam paktek kedokteran sebenarnya dapat disebabkan oleh beberapa kemungkinan, yaitu: Pertama, Hasil dari suatu perjalanan penyakit atau komplikasi penyakit yang tidak ada hubungannya dengan tindakan medik yang dilakukan dokter. Kedua, Hasil dari suatu risiko yang tidak dapat dihindari (Ari Yunanto dan Helmi, 2010: 56). Merujuk dari uraian-uraian di atas, pada dasarnya terhadap risiko medis dokter tidak dapat dimintai suatu pertanggungjawaban hukum sepanjang telah melakukan tindakan sebagaimana telah dijelaskan di atas dikarenakan malpraktek medis dan risiko medis adalah dua hal yang berbeda (Daniel Kessler, 2011: 93).

Pada dasarnya risiko medis tidak dapat dimintakan pertanggungjawaban kepada dokter sepanjang dokter telah melakukan tindakan sesuai dengan standar prosedur, dan sesuai dengan ketentuan pengobatan yang telah diterima secara betul oleh khalayak dokter. Di negara-negara Common Law terdapat suatu doktrin yang biasa digunakan sebagai alasan pembenaran dokter terhadap satu kegagalan medis, yaitu: Risiko didalam pengobatan (Risk of treatment) (i) Risiko yang melekat (ii) Risiko dari akibat reaksi alergi (iii) Risiko yang telah timbul dalam tubuh pasien (iv) Kecelakaan atau (mishap, accident, misadventure, mischance) (v) Kekeliruan dalam penilaian klinis atau (non negligent error of clinical judgment) (vi) Volent non fit iniura, dan (vii) Contributory negligence (K.P.S. Mahalwar, 2013: 161).

Resiko medis juga memiliki sifat tidak dapat diprediksi. Berikut adalah beberapa resiko yang tidak dapat diperiksi dalam tindakan dokter:

1) Resiko pengobatan inheren atau melekat

Setiap tindakan medis yang dilakukan oleh dokter, baik yang bersifat diagnostik ataupun theurepatik akan selalu mengandung resiko yang melakat pada tindakannya itu (Risk Of Treatment). Apabila dokter tersebut melakukannya dengan hati-hati, seizin pasien dan berdasarkan 
standar profesi medik, tetapi resiko tetap terjadi maka dokter itu tidak dapat dipersalahkan. terhadap suatu akibat negatif yang mungkin timbul dari suatu tindakan medis yang tidak dapat diduga sebelumnya misalnya: suatu anafilatic shock pada pemberian anestesi atau obat lain suatu injeksi yang menimbulkan reaksi yang berlebihan dari tubuh pasien itu sendiri, dokter tidak dapat dipersalahkan karena hubungan dokter dan pasien adalah kontrak terapeutik, suatu perjanjian upaya (inspaningsverbintenis) (J. Guwandi, 2009: 105).

2) Resiko komplikasi yang timbul dalam tubuh pasien

Timbulnya komplikasi dalam tubuh pasien yang tidak bisa diketahui atau diduga sebelumnya tidak dapat dipersalahkan kepada dokternya misalnya timbulnya pulmonoly emboli air ketuban dan pasien meninggal setelah menjalani operasi cesar setelah dirawat beberapa hari (J. Guwandi, 2009: 106).

3) Resiko dari alergi atau hipersensitivitas

Resiko alergik adalah resiko berlebihan dari tubuh seseorang karena alergi yang timbulnya secara tiba-tiba yang tidak dapat diprediksi lebih dahulu. Jika alergik ini menimbulkan anafilatic shock maka dokternya tidak dapat dipersalahkan (J. Guwandi, 2009: 107).

Untuk dapat memperkuat argumentasi penulis bahwa kelainan kongenital itu merupakan resiko medis, berikut penulis sajikan penyebeb kelainan kongenital yang diantaranya adalah:

1) Kelainan Kromosom;

Kurang lebih 6\% dari kelainan kongenital disebabkan oleh kelainan kromosom. Ketidakseimbangan kromosom autosom seperti duplikasi, delesi, trisomi dan monosomi dapat menyebabkan abnormalitas perkembangan dan struktur yang berat (Safrina Dewi, 2013: 13).

2) Kerusakan Gen Tunggal; 
Sejumlah kurang lebih 7,5\% dari kelainan kongenital disebabkan oleh kerusakan gen tunggal. Kelainan tersebut dapat bersifat terisolasi atau tidak disertai kelainan lainnya atau bisa juga merupakan bagian dari defek yang lebih luas (Safrina Dewi, 2013: 13-14).

3) Penurunan Multifaktoral;

Faktor genetik telah diketahui dapat menyebabkan sejumlah abnormalitas kongenital mayor. Kebanyakan diantaranya adalah malformasi non-sindroma (isolated) seperti kelainan perkembangan jantung, sistem saraf pusat, dan ginjal (Safrina Dewi, 2013: 15-16).

4) Genetik Heterogenitas;

Genetik heterogenitas (genetic heterogeneity) adalah suatu kondisi yang disebabkan mutasi pada alel yang berbeda atau non-alelik. Sehingga ciri-ciri fenotip lebih diutamakan daripada genotip sebagai dasar ditegakkannya diagnosis (Safrina Dewi, 2013: 16-17).

5) Pengaruh Obat Dan Bahan Kimia;

Secara keseluruhan obat dan bahan kimia menyebabkan kurang lebih 2\% dari semua kelainan kongenital (Safrina Dewi, 2013: 18).

6) Infeksi Pada Ibu;

Beberapa agen infeksi dapat mempengaruhi embriogenesis dan perkembangan janin. Perkembangan otak, mata, dan telinga adalah bagian yang rentan terhadap infeksi. Beberapa infeksi ibu yang dapat menyebabkan kelainan kongenital adalah sebagai berikut: (i) rubella, (ii) cytomegalovirus, dan (iii) toksoplasmosis (Safrina Dewi, 2013: 18-19).

7) Penyakit Pada Ibu;

Beberapa penyakit pada ibu dapat meningkatka resiko abnormalitas kehamilan. Diantaranya adalah: (i) diabetes militus, (ii) phenylketonuria, dan (iii) epilepsi (Safrina Dewi, 2013: 20-21).

8) Agen Fisik; dan 
Agen fisik dapat berupa radiasi ion dan hipertermia yang berkepanjangan (Safrina Dewi, 2013: 20-21).

9) Malformasi Dengan Penyebab Yang Tidak Diketahui.

Hingga 50\% abnormalitas kongenital tidak diketahui penyebabnya secara pasti. Seperti pada defek ekstremitas terisolasi seperti tidak mempunyai telapak tangan dapat disebabkan oleh hilangnya suplai darah pada saat masa penting pembentukan tunas ekstremitas (limb bud) yang menyebabkan terhentinya proses perkembangan. Berdasarkan studi empiris resiko berulang untuk kasus-kasus tersebut sangat rendah (Safrina Dewi, 2013: 21-22).

Mengacu pada penyebab terjadinya kelainan kongenital diatas, peneliti berpendapat bahwa tidak satupun penyebab terjadinya kelainan kongenital yang merupakan akibat dari tindakan medis. Salah satu resiko medis adalah timbulnya resiko dalam tubuh pasien yang tidak bisa diketahui atau diduga sebelumnya. Menurut peneliti, kelainan kongenital yang diderita pasien termasuk dalam resiko dalam tubuh pasien yang tidak bisa diketahui atau diduga sebelumnya. Hal ini dikarenakan ilmu pengetahuan dan teknologi kedokteraan saat ini belum mampu mendeteksi sejak dini kelainan kongenital ini.

b. Konsekuensi Pertanggungjawaban Hukum Pidana Dokter Spesialis Kandungan Dan Kebidanan Pada Kasus Pasien Dengan Kelainan Kongenital

Sebagai profesi yang diatur secara khusus dalam sebuah undangundang, pada profesi kedokteran berlaku asas hukum lex specialis derogate lege generali. Dengan demikian ketentuan peraturan perundang-undangan yang umum akan dikesampingkan oleh ketentuan peraturan perundangundangan khusus. Profesi kedokteran diatur secara khusus di dalam UndangUndang Nomor 29 Tahun 2004 Tentang Praktek Kedokteran.

Dalam pembahasan sebelumnya ditemukan bahwa kelainan kongenital bukan merupakan malpraktek medis melainkan resiko medis. Hal ini 
dikarenakan sifat kelainan kongenital yang merupakan kelainan bawaan dari pasien yang tidak ada sangkut pautnya dengan tindakan medis yang diberikan dokter spesialis kandungan dan kebidanan.

Ketentuan hukum pidana secara umum mengatur bahwa pertanggungjawaban hukum pidana mensyaratkan hubungan kausalitas antara perbuatan (pidana) yang dilakukan seseorang dengan kerugian yang dialami oleh orang lain. Sementara dalam kasus pasien dengan kelainan kongenital, ketentuan tersebut tidak dapat terpenuhi karena tidak terdapat kausalitas antara tindakan medis yang diberikan oleh dokter spesialis kandungan dan kebidanan dengan kelainan kongenital yang diderita pasien. Dalam ketentuan peraturan perundang-undangan yang mengatur secara khusus praktek kedokteran (Undang-Undang Nomor 29 Tahun 2004 Tentang Praktek Kedokteran) juga tidak dapat ditemui konsep pertanggungjawaban hukum pidana yang termasuk dalam konteks kasus pasien dengan kelainan kongenital. Yang ada hanyalah konsep pertanggungjawaban hukum pidana terhadap pelanggaran administratif dalam menjalankan praktek kedokteran.

Dalam Undang-Undang Nomor 29 Tahun 2004 Tentang Praktek Kedokteran bahkan tidak ada ketentuan yang mengatur tentang malpraktek medis yang dilakukan oleh profesi kedokteran maupun resiko medis dalam menyelenggarakan praktek kedokteran. Sehingga sampai saat ini tidak ada rujukan hukumnya apabila ada dugaan malpraktek medis dari pasien maupun penjelasan resiko medis oleh profesi kedokteran. Hal ini sangat disayangkan mengingat konseptualisasi malpraktek medis dan resiko medis dalam bidang akademis sudah sangat banyak, akan tetapi belum diatur dalam sebuah peraturan perundang-undangan padahal praktek kedokteran sendiri acap kali bersinggungan dengan dugaan malpraktek medis maupun penjelasan resiko medis.

Dari observasi yang sudah penulis lakukan dalam pembahasan sebelumnya dapat dikatakan bahwa tidak ada konsep pertanggungjawaban 
hukum yang dapat diterapkan pada kasus pasien dengan kelaianan kongenital. Dengan demikian maka dalam konsep pertanggungjawaban hukum yang diatur dalam peraturan perundang-undangan secara umum maupun peraturan perundang-undangan secara khusus, dokter spesialis kandungan dan kebidanan tidak dapat dimintai pertanggungjawaban hukum pidana dalam kasus pasien dengan kelainan kongenital.

\section{Simpulan}

Kasus pasien dengan kelainan kongenital bukan merupakan malpraktek medis melainkan resiko medis. Dalam kasus ini, kelainan yang diderita oleh pasien merupakan kelainan bawaan yang tidak ada hubungannya dengan tindakan medis yang diberikan oleh dokter spesialis kandungan dan kebidanan. Oleh karena itu, dokter spesialis kandungan dan kebidanan tidak dapat dimintai pertanggungjawaban hukum pidana dalam kasus pasien dengan kelainan kongenital.

\section{E. Saran}

1. Sebaiknya badan legislatif melakukan peninjauan Undang-Undang Nomor 29 Tahun 2004 tentang Praktik Kedokteran dengan menambahkan ketentuan mengenai malpraktek medis dan resiko medis untuk memberikan kepastian hukum pada profesi kedokteran maupun pasien dalam praktek penyelenggaraan pelayanan kesehatan.

2. Sebaiknya profesi dokter spesialis kandungan dan kebidanan mampu menjelaskan dengan baik terkait kelainan kongenital kepada pasien yang mengalaminya, agar tidak terjadi salah paham dan permasalahan di kemudian hari. 


\section{F. Daftar Pustaka}

Ari Yunanto dan Helmi. 2010. Hukum Pidana Malpraktik Medis, Tinjauan, dan Perspektif Medikolegal. Yogyakarta: Andi.

Daniel Kessler. 2011. "The U.S. Malpractice System”. National Institute Of Health. Vol. 2. No. 5.

J. Guwandi. 2009. Pengantar Ilmu Hukum Dan Bio-Etika. Jakarta: Fakultas Kedokteran Universitas Indonesia.

. 2014. Hukum Medik. Jakarta: Fakultas Kedokteran Universitas Indonesia.

Johnny Krisnan. 2008. Sistem Pertanggungjawaban Pidana Dalam Perspektif Pembaharuan Hukum Pidana Nasional. Tesis. Semarang: Universitas Diponegoro.

K.P.S. Mahalwar. 2013. Medical Negligence And The Law. Deep Pubications.

Leden Marpaung. 1991. Unsur-Unsur Perbuatan Yang Dapat Dihukum. Jakarta: Sinar Grafika.

M.S. Ariijaal. 2015. http://www.hukumpedia.com/msarrijaal/malpraktik-medisvs-resiko-medis, diakses pada pukul 11.05 WIB, tanggal 13 Agustus 2017

Moeljatno. 1984. Asas-Asas Hukum Pidana. Jakarta: Bina Aksara

Peter Mahmud Marzuki. 2014. Penelitian Hukum. Jakarta: Penerbit Prenadamedia Group.

Riza Alfiano Kurniawan. 2013. "Resiko Medis Dan Kelalaian Terhadap Dugaan Malpraktek Medis Di Indonesia”. Perspektif. Vol. 8. No. 3.

Rosa Elita dan Yusuf Shofie. 2007. Malpraktek, Penyelesaiian Sengketa, dan Perlindungan Konsumen. Jakarta: Unika Atma Jaya.

Safrina Dewi. 2013. Kelainan Kongenital. Malang: Universitas Brawijaya.

Samuel Setiawan Sutarmanto dan Pujiyono. "Sinkronisasi Peraturan Pemerintah Nomor 29 Tahun 1999 Tentang Pembelian Saham Bank Umum Dan Peraturan Bank Indonesia Nomor 14/8/PBI/2012 Tentang 
Kepemilikan Saham Bank Umum”. Jurnal Hukum Dan Pembangunan Ekonomi. Vol. 4. No.2.

Soekidjo Notoatmojo. 2010. Etika dan Hukum Kesehatan. Jakarta: Rineka Cipta.

Titik Triwulan dan Shinta Febrian. 2010. Perlindungan Hukum Bagi Pasien. Jakarta: Prestasi Pustaka.

Wahyu Wiriadinata. 2014. "Dokter, Pasien, Dan Malpraktek". Mimbar Hukum. Vol. 26. No 1. 